\title{
非天然金属中心をもつ新たな還元酵素
}

\section{A New Reductase Containing Non-natural Metal Active Site}

小野田 晃* (大阪大学大学院工学研究科)

Department of Applied Chemistry, Graduate School of Engineering, Osaka University, Akira Onoda*

Received July 31, 2010; E-mail: onoda@chem.eng.osaka-u.ac.jp

\begin{abstract}
One useful synthetic reaction missing from nature's toolbox is the direct hydrogenation of substrates using hydrogen. To create an enzyme that can directly reduce organic substrates with hydrogen, researchers have combined metal hydrogenation catalysts with proteins. A direct hydrogenation of olefins catalyzed by rhodium(I) bound to carbonic anhydrase (CA) was reported by Kazlauskas and the colleagues recently. They minimized nonspecific binding of rhodium by replacing histidine residues on the protein surface using site-directed mutagenesis or by chemically modifying the histidine residues. Hydrogenation catalyzed by their $\mathrm{Rh}$-bound CA is slightly slower than for uncomplexed rhodium(I), but the protein environment induces stereoselectivity favoring cis- over trans-stilbene by about 20:1. This enzyme is the first cofactor-independent reductase that reduces organic molecules using hydrogen.
\end{abstract}

天然の酵素は、広範な化学反応を効率的に触媒する機 能をもつている反面、その対象は生命活動に有益な反応 に限定されているともいえる。したがって、生体反応の 枠組みの外に着眼すれば、新しい反応を触媒するタンパ ク質の創出につながる。天然の酵素がもたない反応性で、 有機合成化学では一般的で重要な反応の一つが、水素 分子を還元剤とする水素化反応である。生体系では、ヒ ドロゲナーゼが水素分子からプロトンと電子を取り出す が、有機分子の還元には関与しない。通常の代謝過程で は、有機分子を還元する際には、 $\mathrm{NAD}(\mathrm{P}) \mathrm{H}$ や、 $\mathrm{FADH}_{2}$ を用いている。生体系では、これらの補因子を使うこと で、酵素内の活性部位にて補因子と基質を近接させ、か つ、適切な配置に固定化できるので、反応効率を高める ことができる。また、異なる酸化還元電位の補因子を使 うことで、細胞内で様々な物質の還元を効率的に行うこ とができる。しかし、補因子の安定性や価格の点を考慮 すれば、単離したタンパク質を用いた反応系の場合には、 補因子を使わない水素化にも利点がある。

水素分子による還元反応を触媒する酵素を創製するた

連絡先著者名: 小野田晃

連絡先 : 565-0879 大阪府吹田市山田丘 2-1

大阪大学大学院工学研究科

Tel: 06-6879-7929 Fax: 06-6879-7930

Corresponding Author: Akira Onoda

Address: 2-1 Yamadaoka, Suita, Osaka 565-0879, Japan

Keywords:artificial metalloproteins, protein modification, rhodium catalyst, hydrogenation
めに、これまでに金属触媒とタンパク質を組み合わせた 系が報告されている ${ }^{1), 2)}$ 。Ward らは、ロジウムのホスフ イン配位子にリンカーを介してビオチンを導入し、この 触媒ユニットをビオチンーアビジン間の強力な分子間相 互作用によって、アビジン内に埋め込む手法を発展させ、 高エナンチオ選択的な水素化反応を達成している ${ }^{3), 4)}$ 。 また、モノクローナル抗体にロジウムホスフィン錯体を 取り込ませた系においても、高いエナンチオ選択性に成 功した例がある ${ }^{5)}$ 。このように触媒部位を分子間相互作 用で固定するアプローチの他には、タンパク質の側鎖を ロジウムの配位子として直接利用している例もあるが、 選択性は概して低い。一方、フェリチンの内部空間（約 $12 \mathrm{~nm})$ に、パラジウム粒子を直接埋め込んだ系では、 基質分子のサイズ選択的な水素化反応が報告されてい る ${ }^{6)}$ 。

Kazlauskas らは、活性中心の金属イオンの置換によっ て新しい反応性をタンパク質に組み込むアプローチに取 り組んでおり、最近、炭酸脱水素酵素 (CA) の活性中心 の亜鉛をロジウムに置換したタンパク質が、スチルベン の触媒的水素化反応においてシス体選択性をもつことを 報告した7)。CA を亜鉛キレーターである 2,6-ピリジン カルボン酸の存在下で透析をおこない、活性中心の亜鉛 を取り除いてアポ体を調製した後に、 $\left[\mathrm{Rh}(\operatorname{cod})_{2}\right] \mathrm{BF}_{4}(\operatorname{cod}$ =1,5-cyclooctadiene) を加えることで、ロジウム (I) 導 入した CA を調製した $($ Scheme 1)。アイソフォームであ る human CAII 及び bovine CAII を用いたいずれの場合 においても、活性中心だけでなく、タンパク質の表面に もロジウムが約 5 当量程度錯形成していることを、ICPMS による金属定量と Bradford 法によるタンパク質定量 から示している。この方法で得た置換タンパク質では、 過鄱のロジウムはタンパク質表面のヒスチジンやリジン 残基に結合している可能性が高いと考えられる。そこ で、 diethylpyrocarbonate (DEPC) 処理によって、タンパ ク質表面のヒスチジンイミダゾール窒素に選択的にエト キシカルボニル基の修飾をおこなった。一方で、このよ うな修飾はタンパク質の構造的な安定性を損なうので、 表面のヒスチジン残基をアミノ酸置換 (His3/4/10/36Arg, His15/17/107/122Phe, His64Ala) することで安定性を向 上させている。彼らは、部位特異的変異導入と化学修飾 を合わせることで、活性部位以外に 1.3 当量しか過剩の 
ロジウムが結合していないタンパク質触媒の構築に成功 した。

次に、得られた CA 触媒を用いて、cis-スチルベンの 水素化反応を水溶液中（MES バッファー）にておこな つた (Scheme 2)。比較として原料の $\left[\mathrm{Rh}(\operatorname{cod})_{2}\right] \mathrm{BF}_{4}$ につ いても MES バッファーにて反応を行ったところ、水素 化 $(80.0 \%)$ と同時に trans-スチルベンへの異性化反応 も (12.6\%) 進行するが、この水素化と異性化の比率 $(\mathrm{H} /$ I 比 ) は 6.3 であり水素化の選択性は低かった。同様に、 タンパク質表面にロジウムが結合した置換タンパク質 では、H/I 比は 0.9 であり選択性は低い。また、表面に 結合した金属が 1.3 当量と少ないロジウム CA では、H/ I 比が 16.7 と選択性が高いことから、活性中心に導入し たロジウムが水素化の触媒活性に寄与していると考えら れる。また、シス体との反応性が、トランス体に比べて、 20 倍以上高かった。活性部位近傍の基質認識部位の構 造的なシミュレーションからも、シス体の方が、より適 切な配置になることが示唆された。

彼らのロジウム CA は、ホスフィン配位子を介さずに 活性部位のアミノ酸側鎖に直接配位したロジウム（I） が活性点となって水素化反応を触媒しており、この点は 非常に興味深い。克服すべき点として、金属イオンの導 入を活性部位に完全には限定できずタンパク質表面にも 錯形成してしまうこと、タンパク質マトリクスの中では 反応が失速していることが挙げられるが、活性部位の金 属置換を軸に、酵素が持つ反応性を広域化して還元酵素 を作製した点で意義は大きい。

一方で、金属を含まない人工酵素の開発では、活性部 位近傍のアミノ酸を、網羅的なコンピューターデザイン と実験室進化を駆使することで最適化をおこない、新 しい反応を触媒する酵素の作製に成功した報告がある ${ }^{8)}$, 9)。今後は、このようなアプローチも取り入れることで、 遷移金属触媒がもつ多様な反応性を、タンパク質内部へ 機能移植できれば、タンパク質進化の過程で選択されな かつた触媒能をもつ人工タンパク質を創り出すことにな る。今後もタンパク質内部への様々な金属活性点の構築 とその反応性の開拓が期待される。

文献

1) D. F. Qi, C. M. Tann, D. Haring and M. D. Distefano, Chem. Rev, 101, 3081 (2001).

2) C. M. Thomas and T. R. Ward, Chem. Soc. Rev., 34, 337 (2005).

3) M. Skander, N. Humbert, J. Collot, J. Gradinaru, G. Klein, A. Loosli, J. Sauser, A. Zocchi, F. Gilardoni and T. R. Ward, J. Am. Chem. Soc., 126, 14411 (2004).

4) J. Collot, J. Gradinaru, N. Humbert, M. Skander, A. Zocchi and T. R. Ward, J. Am. Chem. Soc., 125, 9030 (2003).

5) H. Yamaguchi, T. Hirano, H. Kiminami, D. Taura and A. Harada, Org. Biomol. Chem., 4, 3571 (2006).

6) T. Ueno, M. Suzuki, T. Goto, T. Matsumoto, K. Nagayama and Y.
Watanabe, Angew. Chem., Int. Ed., 43, 2527 (2004).

7) Q. Jing, K. Okrasa and R. J. Kazlauskas, Chemistry Eur. J., 15, 1370 (2009).

8) D. Rothlisberger, O. Khersonsky, A. M. Wollacott, L. Jiang, J. DeChancie, J. Betker, J. L. Gallaher, E. A. Althoff, A. Zanghellini, O. Dym, S. Albeck, K. N. Houk, D. S. Tawfik and D. Baker, Nature, 453, 190 (2008).

9) L. Jiang, E. A. Althoff, F. R. Clemente, L. Doyle, D. Rothlisberger, A. Zanghellini, J. L. Gallaher, J. L. Betker, F. Tanaka, C. F. Barbas, D. Hilvert, K. N. Houk, B. L. Stoddard and D. Baker, Science, 319, 1387 (2008).

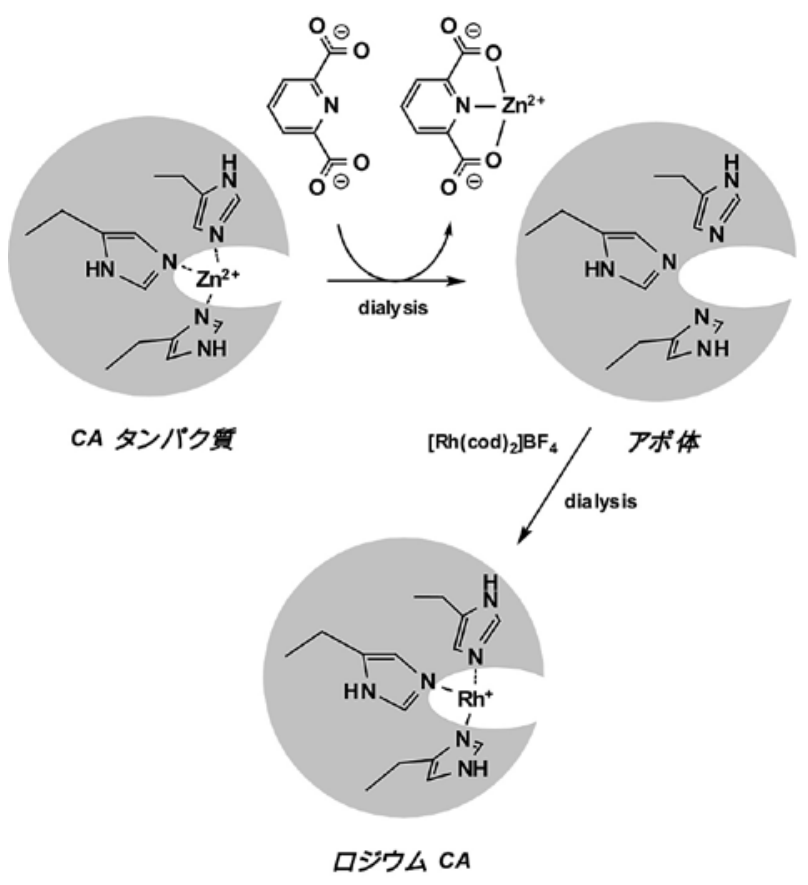

Scheme 1

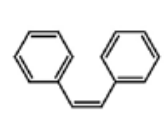

cis-stilbene

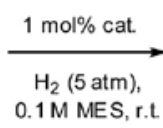
$0.1 \mathrm{M}$ MES, r.t

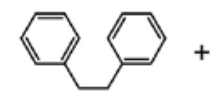

bibenzyl (hydrogenation)

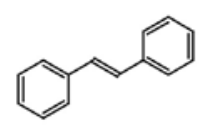

trans-stilbene (isomerization)
MES $=2-(N-$ mor pholino $)$ ethanesulfonic acid

Scheme 2 